\title{
0 ensino de inglês em jogo: experiências práticas com o uso do cinema em um curso de informática integrado ao ensino médio
}

\author{
Mateus da Rosa Pereira ${ }^{1}$ \\ Clarice Maria de Sousa Portela Germann Teixeira ${ }^{2}$ \\ Danielle dos Santos Espíndula ${ }^{3}$ \\ Maiara Dalpiaz dos Santos ${ }^{4}$ \\ Sheila Roberta Schweig ${ }^{5}$
}

\begin{abstract}
"Sometimes it is the people no one can imagine anything of who do the things no one can imagine." ( 0 jogo da imitação, 2014)
\end{abstract}

\section{RESUMO}

O cinema pode ser um grande aliado no ensino de inglês, desde que algumas preocupações sejam levadas em consideração, tais como as necessidades específicas da turma, o contexto educacional concreto e o nível de proficiência dos alunos. A fim de fortalecer as práticas de ensino com o uso desse recurso tão apreciado pelos estudantes, em 2017 investigamos um referencial teórico básico sobre as relações entre a linguagem cinematográfica e a Língua Inglesa (PEREIRA; ESPÍNDULA; TEIXEIRA, 2018). Ao longo de 2018, um novo projeto dedicou-se a desenvolver atividades que dialoguem com os pressupostos teóricos estudados, com 0 objetivo de retroalimentar as pesquisas e enriquecer as práticas de ensino. Nesse contexto, o presente trabalho narra algumas atividades desenvolvidas na disciplina de Língua Inglesa IV, com uma turma de formandos do curso técnico em informática integrado ao ensino médio do IFRS. Com base no filme o jogo da imitação (2014), essas atividades entrelaçam habilidades produtivas e receptivas, além de desenvolver vocabulários relacionados à área técnica do curso e fomentar a conscientização linguística a respeito dos sentidos e usos de adverbial clauses no contexto temático e narrativo do filme. Ao final, são tecidas algumas reflexões a respeito dos resultados alcançados e do uso de filmes no ensino de inglês.

PALAVRAS-CHAVE: Ensino de Língua Inglesa. Cinema em sala de aula. Filmes.

\section{ABSTRACT}

Films can be a great aid in English Language Teaching (ELT), as long as we take into account some concerns, such as the specific needs of the class, the concrete educational context, and the proficiency level of our students. In order to strengthen the educational practices using a teaching aid that is widely appreciated by our students, in 2017 we investigated a basic theoretical framework about the relationship between film language and English language (PEREIRA; ESPÍNDULA; TEIXEIRA, 2018). As a follow-up project, in 2018 we have been designing activities that address the theoretical foundations studied, aiming to feedback the research and enrich educational practices. In this context, this paper describes the activities developed in

${ }^{1}$ Doutor em Letras pela Universidade Federal do Rio Grande do Sul (UFRGS). Professor de Português e Inglês no Instituto Federal de Educação, Ciência e Tecnologia do Rio Grande do Sul (IFRS), Campus Osório. E-mail: mateusdarosapereira@yahoo.com.br

${ }^{2}$ Acadêmica do curso de Licenciatura em Letras - Português/Inglês, IFRS, Campus Osório. E-mail: claricemsportela@hotmail.com

${ }^{3}$ Acadêmica do curso de Licenciatura em Letras - Português/Inglês, IFRS, Campus Osório. E-mail: danielle.espindula@hotmail.com

${ }^{4}$ Acadêmica do curso de Licenciatura em Letras - Português/Inglês, IFRS, Campus Osório. E-mail: mayadalpiaz@gmail.com

${ }_{5}^{5}$ Acadêmica do curso de Licenciatura em Letras - Português/Inglês, IFRS, Campus Osório. E-mail: schweig.sheila@gmail.com 
English Language 4, with a class of senior students from the computer science program integrated into the high school of the Federal Institute of Education in the State of Rio Grande do Sul (IFRS). Based on the film The Imitation Game (2014), the activities bring together productive and receptive skills, develop vocabulary related to the technical field of computer science, and raise students' linguistic awareness about the usage and meanings of adverbial clauses in the thematic and narrative context of the movie. Some final considerations are also presented about the outcomes that were reached and about using films in ELT.

KEYWORDS: English language teaching. Technical high school. Instructional activities.

\section{Introdução}

As atividades narradas nesta publicação são resultantes dos trabalhos desenvolvidos no âmbito do projeto de pesquisa “O uso do cinema no ensino da Língua Inglesa em um curso técnico em informática integrado ao ensino médio do IFRS", desenvolvido com discentes do curso de Licenciatura em Letras do campus Osório. No ano de 2017, outro projeto de pesquisa ${ }^{6}$ investigou um referencial teórico básico sobre o uso do cinema no ensino de Língua Inglesa (LI), e apresentou uma proposta metodológica com atividades concretas que podem ser implementadas na docência dessa língua estrangeira (PEREIRA; ESPÍNDULA; TEIXEIRA, 2018). Embora as atividades aqui apresentadas dialoguem diretamente com as pesquisas conduzidas até o momento, elas abordam o filme selecionado de uma maneira um pouco mais ampla, para além da mise-en-scène, relacionando elementos da narrativa filmica e de sua linguagem cinematográfica, que também engloba a cinematografia, o enquadramento, as relações rítmicas, espaciais $e$ temporais entre as tomadas (edição), bem como as dimensões e funções do uso do som (cf. BORDWELL \& THOMPSON, 2008, p. 112).

O contexto educacional para o qual as atividades foram desenvolvidas é o de uma turma do quarto ano do curso técnico em informática integrado ao ensino médio, o que explica a escolha do filme 0 jogo da imitação (2014), sobre a vida de Alan Turing, matemático britânico que desenvolveu uma máquina considerada a precursora do computador. A decisão de desenvolver tarefas que dialoguem com a linguagem cinematográfica de forma mais ampla surgiu principalmente de três fatores: (a) das interações com as turmas do ensino médio desde o início do projeto e com base no

\footnotetext{
${ }^{6} O$ projeto de pesquisa " 0 uso do cinema no ensino da língua inglesa: a mise-en-scène" foi um estudo teórico que buscou explorar as relações entre a linguagem filmica e a linguística aplicada ao ensino do inglês e gerou, entre outros produtos, 0 artigo " $O$ ensino da Língua Inglesa em tela: a mise-en-scène" (PEREIRA; ESPÍNDULA; TEIXEIRA, 2018).
} 
feedback coletado informalmente ao longo das aulas do professor regente e coordenador do projeto; (b) da dificuldade de identificar um aspecto específico da linguagem cinematográfica que se relacione com as orações adverbiais, tópico linguístico a ser trabalhado no caso em questão; e da (c) vontade de trabalhar várias cenas do mesmo filme, com atividades diversificadas que possam dar conta de apresentar, praticar e revisar o tópico linguístico em questão ${ }^{7}$. Acreditamos que essa mudança de foco não invalide as propostas metodológicas anteriormente exploradas, já que há infinitas possibilidades de trabalharmos a linguagem audiovisual nas aulas de língua estrangeira. Ademais, uma de nossas premissas para o trabalho com o audiovisual no ensino de LI sempre esteve na base do nosso planejamento e da nossa prática docente, ou seja, a necessidade de partir dos objetivos pedagógicos para depois definirmos como utilizar o material audiovisual com 0 intuito de atingir tais objetivos, evitando, assim, que a aula de inglês se transforme em uma situação de baby-sitting, em que o professor apenas toma conta da turma enquanto ela se diverte $^{8}$, conforme bem aponta Khan (2015, p. 50).

A relevância do desenvolvimento de atividades com cinema para um curso técnico em informática parte da constatação de que os livros didáticos do Programa Nacional do Livro Didático disponíveis para o ensino de inglês no ensino médio não contam com conteúdos linguísticos específicos das áreas técnicas. Nesse sentido, a preparação de um repositório virtual, na forma de um site, que reúne atividades para o ensino de inglês com o uso de filmes, pode significar uma solução para essa necessidade de gerar conteúdos de aprendizagem da língua estrangeira no contexto do ensino técnico. Por isso, um dos objetivos do trabalho desenvolvido pelo projeto de pesquisa mencionado é alimentar um repositório virtual que possa auxiliar professores de LI com propostas de atividades, que podem ser adaptadas às suas realidades específicas ou apenas servir para gerar outras ideias de aplicações. As atividades aqui narradas são a aplicação de sequências didáticas elaboradas e disponibilizadas nesse ambiente (CINEMA E LÍNGUA INGLESA, online).

\footnotetext{
${ }^{7}$ Apesar de acreditarmos que o uso de trechos de um filme possa ser mais facilmente relacionado com objetivos pedagógicos específicos de um plano de ensino, a vontade de trabalhar com um filme todo, realizando uma série de atividades, foi estimulada pelo trabalho publicado por Alice Canal (2017), em que a autora utiliza o filme Um conto chinês (2011) ao longo de algumas aulas no ensino do espanhol.

${ }^{8}$ Embora isso possa parecer uma observação banal do ponto de vista da linguística aplicada, na prática pedagógica frequentemente constatamos que, quando os professores decidem trabalhar com um filme em sala de aula, existe uma tendência a deixar os objetivos didáticos em segundo plano, senão em completo esquecimento, conforme desenvolvido em outra publicação (PEREIRA; ESPÍNDULA; TEIXEIRA, 2018, p. 24-25).
} 


\section{LínguaTec}

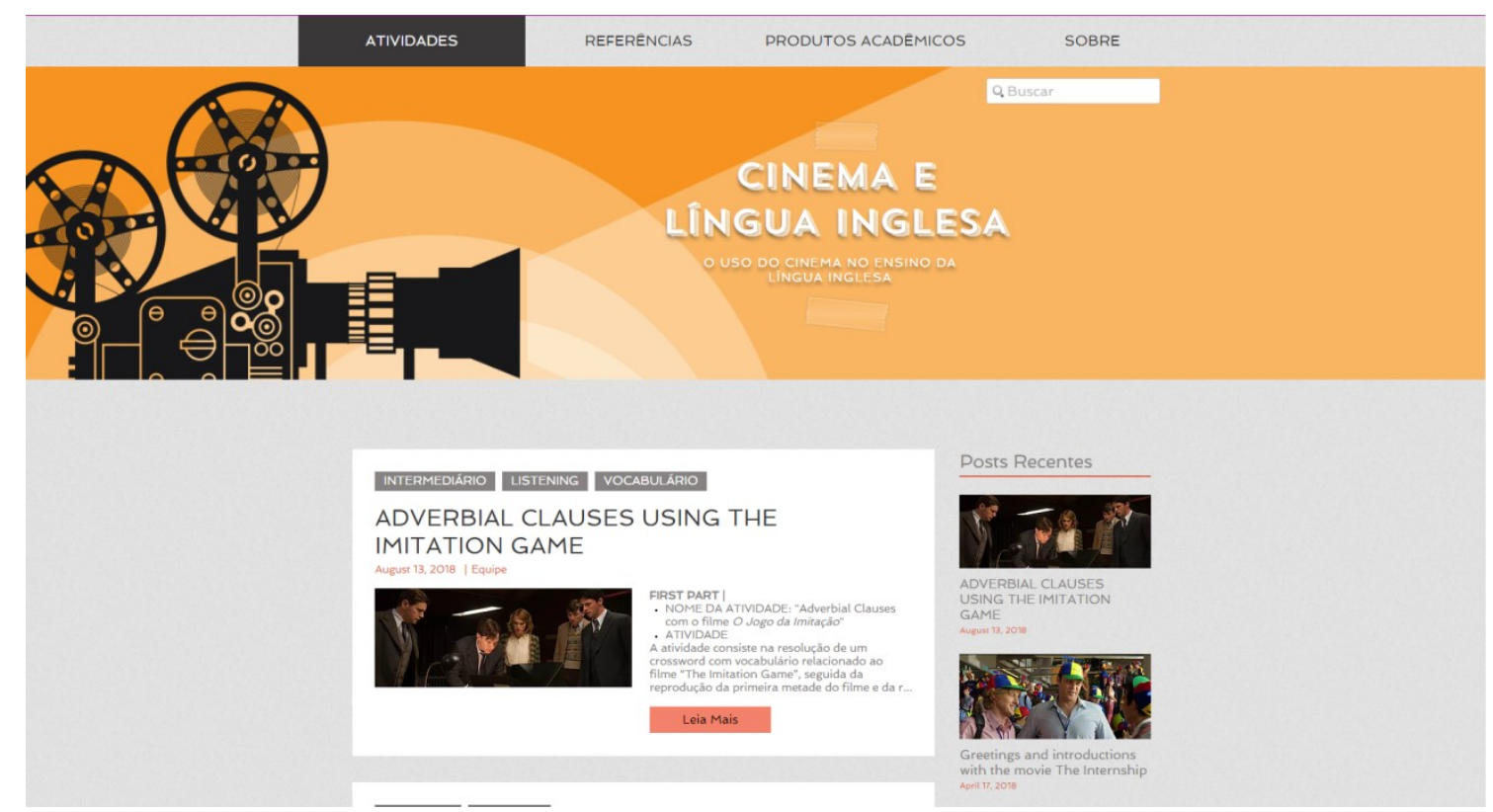

Imagem 1. Página inicial do site Cinema e Língua Inglesa

Fonte: Cinema e Língua Inglesa (2018)

Gostaríamos de ressaltar que todas as atividades narradas nesta publicação foram discutidas, antes e depois de suas aplicações, durante vários encontros de pesquisa, realizados no Centro de Ensino de Línguas e Literaturas (CELL) do campus Osório, um espaço dedicado a promover a relação entre teorias e práticas de sala de aula, utilizando vivências da realidade escolar para fortalecer o ensino de línguas e literaturas para os alunos de ensino médio e superior. Nesse sentido, as atividades também fazem parte da formação de quatro discentes do curso de Letras, que entraram em contato com a realidade do ensino de inglês de forma gradativa e amparada pelo referido projeto de pesquisa e tiveram a oportunidade de refletir sobre vários aspectos que surgiram durante a elaboração, a aplicação e a avaliação das atividades.

As atividades didáticas apresentadas a seguir foram convenientemente divididas em quatro seções, pois foram realizadas no decorrer de quatro semanas, ocupando aproximadamente 350 minutos de ensino-aprendizagem. Por trás da organização dessas tarefas, tentamos sempre dividir as atividades em "antes", "durante" e "depois" do filme, seguindo a recomendação de Khan (2015, p. 49), e levando em consideração também os princípios explorados por Brown para o desenvolvimento das habilidades receptivas (Brown, 2007, p. 310-312; 373-376), já que consideramos o audiovisual como um recurso pedagógico complexo, um insumo composto por múltiplas camadas semióticas. 
Antes de passarmos à narrativa das atividades, cumpre esclarecermos brevemente nossa abordagem do tópico linguístico selecionado a partir do Plano de Ensino da disciplina de Língua Inglesa IV. Ao longo das atividades com o tema adverbial clauses, nossa prática se pautou no objetivo de trabalhar com aspectos formais da LI de maneira contextualizada e ligada a propósitos comunicativos, levando em consideração que a gramática é apenas uma das dimensões de um tripé também formado pela semântica e pela pragmática. Nesse sentido, os exercícios desenvolvidos com o filme estabeleceram relações entre formas e sentidos, pois consideramos, durante as análises, quem era o falante, quem era o públicoalvo e onde a comunicação estava acontecendo, entre outras questões (cf. BROWN, 2007, p. 420).

\section{A primeira aula: as regras do jogo}

No dia 13 de agosto de 2018, os formandos do curso técnico em informática integrado ao ensino médio trabalharam com a primeira metade do filme O jogo da imitação. A turma não sabia qual seria o filme, então, como forma de instigar os alunos para que eles descobrissem qual seria o nome do filme, receberam um crossword (Anexo 1$)^{9}$ que, quando completo, tinha palavras que caracterizavam os temas e a narrativa da obra. A atividade apresentou alguma dificuldade por conter um vocabulário bem específico, e mesmo os alunos que estão em um nível mais avançado de proficiência não conseguiram completar uma ou duas palavras. Mesmo assim, eles deram palpites sobre qual seria o filme, até que um aluno sabia qual era.

${ }^{9}$ Os anexos, entre outros materiais mencionados nesta narrativa, estão disponíveis para download no site CINEMA L LINGUA INGLESA. Disponivel em: $<$ https://cinemaelinguainglesa.wixsite.com/cinemaelinguainglesa>. 


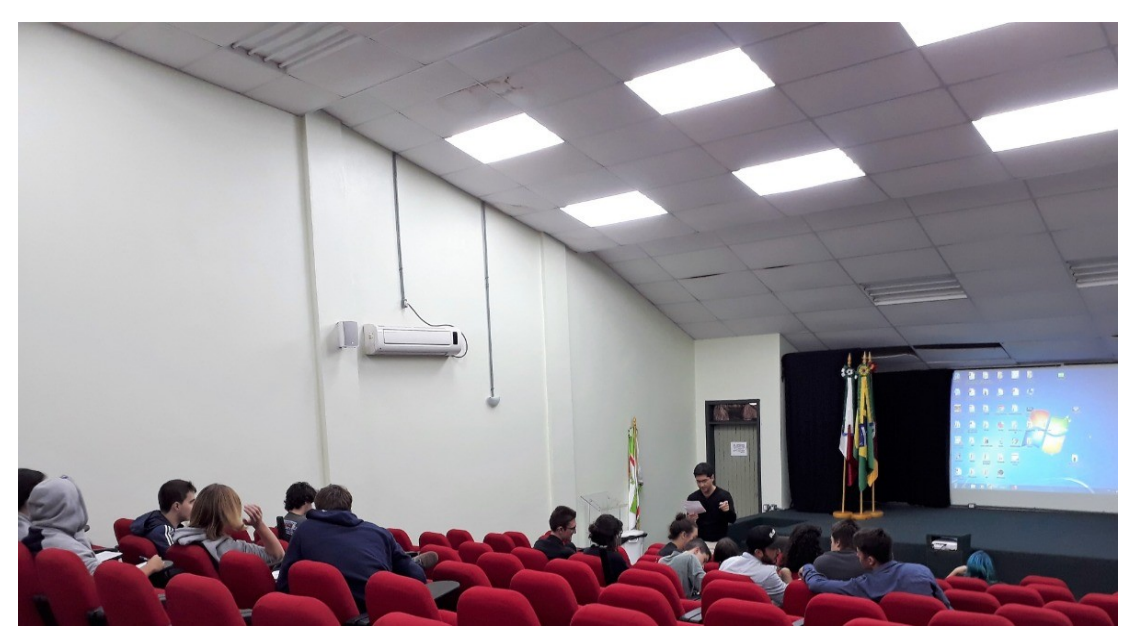

Foto 1. Antes de descobrir a que filme a turma assistiria, os alunos tiveram que resolver uma cruzadinha, elemento que desempenha uma função importante no filme.

Fonte: os autores.

Em seguida, foi exibida a primeira parte do filme (56 min.), em inglês com legendas em português ${ }^{10}$. Durante a exibição do filme, os alunos prestaram atenção na história, pois a sua escolha foi feita justamente pelo que ele proporciona de interessante aos alunos, já que Alan Turing, o protagonista, é um gênio da matemática e enfrenta um dos maiores desafios da sua carreira, decifrar o Enigma, código Nazista, e para isso ele tenta criar uma máquina, a qual ele chama de Christopher, que seria capaz de decodificar qualquer um desses códigos e se tornaria o protótipo do que viria a ser um computador.

\footnotetext{
${ }^{10} \mathrm{~A}$ exibição do filme sem legendas, com legendas em inglês ou com legendas em português é uma escolha muito importante durante a concepção das atividades com cinema no ensino de LI, pois gera implicações para o grau de dificuldade dos exercícios. Neste caso concreto, dois motivos principais nortearam nossa decisão. Primeiro, porque o sotaque britânico representa um grau adicional de dificuldade, ainda mais com características linguísticas e maneirismos das décadas de 40 e 50 do século XX. O segundo fator foi o feedback de atividades anteriores, em que alguns alunos, com nível de proficiência mais baixo na turma, consideraram quase impossível entender o filme sem legendas. Foi inclusive relatado, para a surpresa do professor, que na casa de um dos alunos ele nunca havia assistido a um filme a não ser dublado.
} 


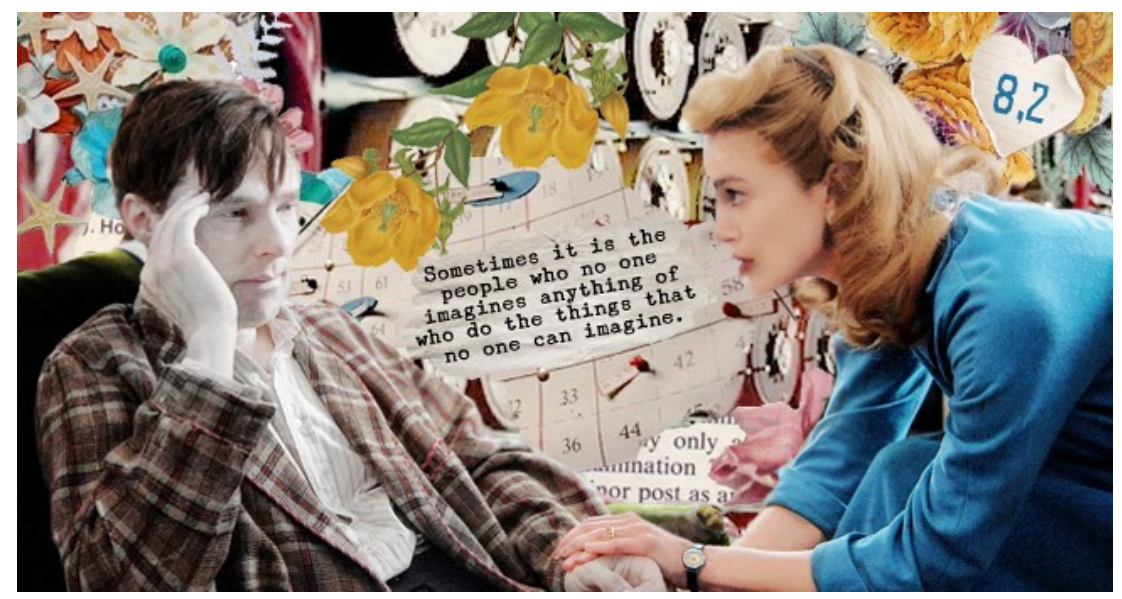

Imagem 2. Alan e Joan, protagonistas do filme O jogo da imitação.

Fonte: Cinematic Corner (2018).

Posteriormente à exibição, foi entregue uma atividade de verdadeiro ou falso (Anexo 2), como forma de perceber se os alunos compreenderam o filme. A última questão dessa atividade, propositalmente, poderia ser qualquer uma das alternativas ( $V$ ou F), pois era justamente para criar uma discussão, o que de fato aconteceu. Cinco alunos responderam que a questão era verdadeira, e o restante da turma marcou falsa. A questão era sobre Alan ter facilidade em todos os códigos. Os que responderam verdadeiro argumentaram que sim, porque ele era um matemático incrível, já os outros falaram sobre a dificuldade do personagem em entender contextos simples na sua própria língua, como não compreender um convite para almoçar fora.

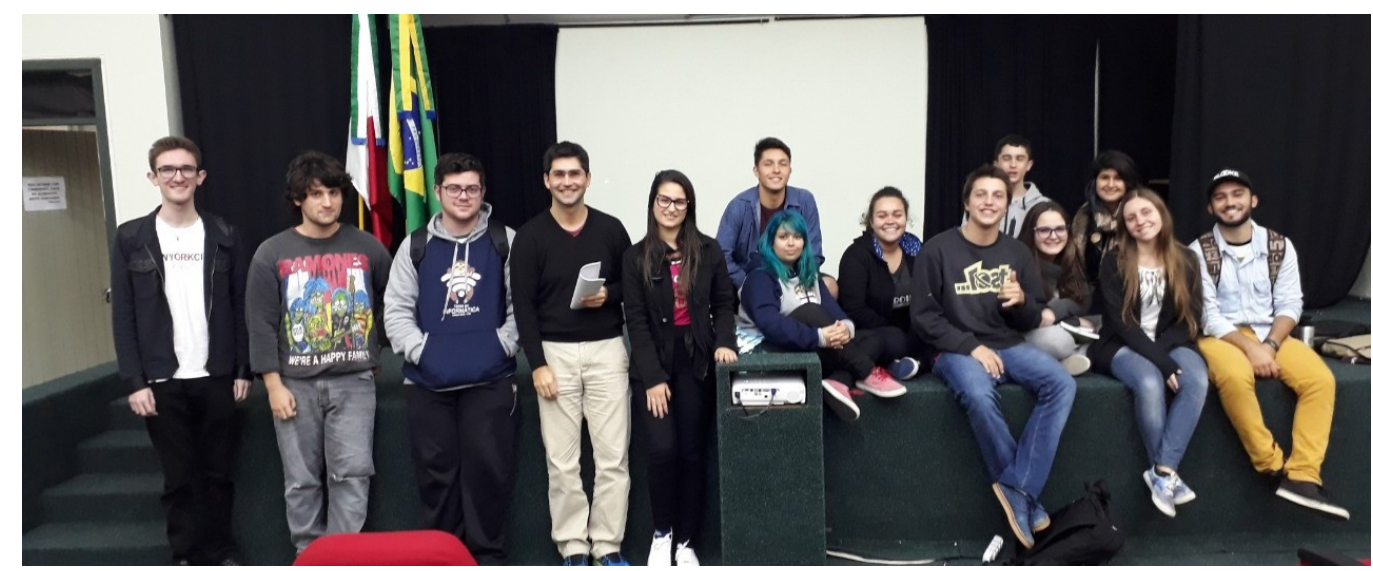

Foto 2. A turma de formandos do curso de informática ao final do primeiro dia de atividades com o filme 0 jogo da imitação, no Auditório do campus Osório do IFRS.

Fonte: os autores. 


\section{A segunda aula: trabalho de conscientização linguística}

No dia 20 de agosto, na sala de aula regular, o professor dedicou um período da aula para o desenvolvimento das atividades do projeto. 0 objetivo dessa aula foi apresentar 0 tópico linguístico das orações subordinadas adverbiais no contexto da primeira metade do filme 0 jogo da imitação. As atividades de compreensão sobre a primeira parte da obra estavam repletas de exemplos do tópico linguístico em questão, já que tínhamos o intuito de proporcionar à turma uma contextualização rica sobre o filme antes de apresentarmos análises linguísticas sobre as orações adverbiais.

As atividades de homework foram corrigidas uma a uma, sem referência explícita ao conteúdo gramatical durante a correção. Em geral, os alunos demonstraram facilidade para resolver o exercício de verdadeiro ou falso, o que evidencia compreensão da narrativa do filme, bem como entendimento das frases criadas a respeito dos conflitos retratados na produção audiovisual. Já na segunda cruzadinha (Anexo 3), que apresenta itens lexicais que completam falas do filme, especificamente da "cena do sanduíche", ${ }^{11}$ os alunos apresentaram certa dificuldade para se lembrar de vocabulários que preenchessem adequadamente as lacunas e se encaixassem no crossword. Esta última atividade representou um desafio para a turma, o que não deixa de ser interessante, pois a própria lógica de resolver um crossword está ligada à solução de um enigma, um desafio, tal como retratado no filme. Apesar disso, talvez fosse interessante, em aplicações futuras dessa atividade, reproduzir novamente essa cena no momento da correção.

Em seguida, o professor selecionou uma frase do exercício de verdadeiro ou falso (Alan closes the door because he wants to protect his machine) e a escreveu no quadro, analisando suas duas orações e identificando a oração subordinada adverbial e sua função. O professor levou a turma a reconhecer que todas as frases do exercício têm orações adverbiais e que elas são introduzidas por palavras específicas (because, so, if, etc.), cada uma com um sentido peculiar. Depois disso, o professor utilizou uma apresentação de slides com a definição do tópico gramatical em questão, com a classificação das orações adverbiais contextualizadas com frases sobre a primeira metade do filme. 0 professor

\footnotetext{
${ }^{11} \mathrm{O}$ que nos referimos como a cena do sanduíche é a sequência em que John convida Alan para almoçar, ao que este parece não estar ouvindo. Na verdade, Alan não aceita que uma assertiva possa desempenhar a função de pergunta e/ou de convite, pois tem dificuldade em entender a função conotativa da linguagem.
} 
enfatizou que mais importante do que memorizar a classificação das orações adverbiais é entender as relações de sentido e aprender vocabulários que têm significados semelhantes aos que eles já conhecem.

Finalmente, para fechar essa parte de conscientização linguística, os alunos voltaram às frases do exercício de verdadeiro ou falso, desta vez para identificar que função e que significado as orações adverbiais apresentavam. Alguns minutos depois, quando os alunos já estavam terminando a atividade, o professor distribuiu um handout com a definição e a classificação das orações adverbiais.

\section{A terceira aula: um jogo não competitivo}

No dia 23 de agosto, quinta-feira, a turma assistiu à segunda metade do filme e realizou tarefas de consolidação do tópico linguístico das orações adverbiais. A aula foi realizada em períodos cedidos por uma professora colega da instituição, pois era um dia em que todos os membros da equipe de pesquisa podiam comparecer e observar o andamento da atividade ${ }^{12}$. Percebemos que os alunos demoraram vários minutos para chegar ao miniauditório, apesar de já terem combinado com o professor que a atividade seria desenvolvida ali, depois do intervalo. Acreditamos que o atraso está associado, de alguma maneira, à crença de que atividade com filmes está alinhada com diversão e não com aprendizado. Fosse essa uma atividade como uma prova, provavelmente os alunos não teriam se atrasado.

O professor retomou com a turma as etapas realizadas até o momento com o filme em questão e explicou que, nesse dia, a turma assistiria à última parte da obra e depois faria uma dinâmica muito interessante sobre o filme. A atividade consistia em um jogo em que os alunos tinham que completar lacunas apresentadas em slides com conjunções para formar frases com advérbios e orações adverbiais. As frases eram falas do filme ou afirmações sobre a narrativa, especificamente relativas à segunda parte da obra.

\footnotetext{
${ }^{12}$ As discentes que integram o projeto de pesquisa são bolsistas voluntárias, por isso quase todas trabalham no dia em que a turma tem suas aulas regulares. Assim, a professora que cedeu sua aula possibilitou que todos os integrantes participassem da atividade, fazendo observação, auxiliando o professor e fazendo o registro fotográfico.
} 


\section{LínguaTec}

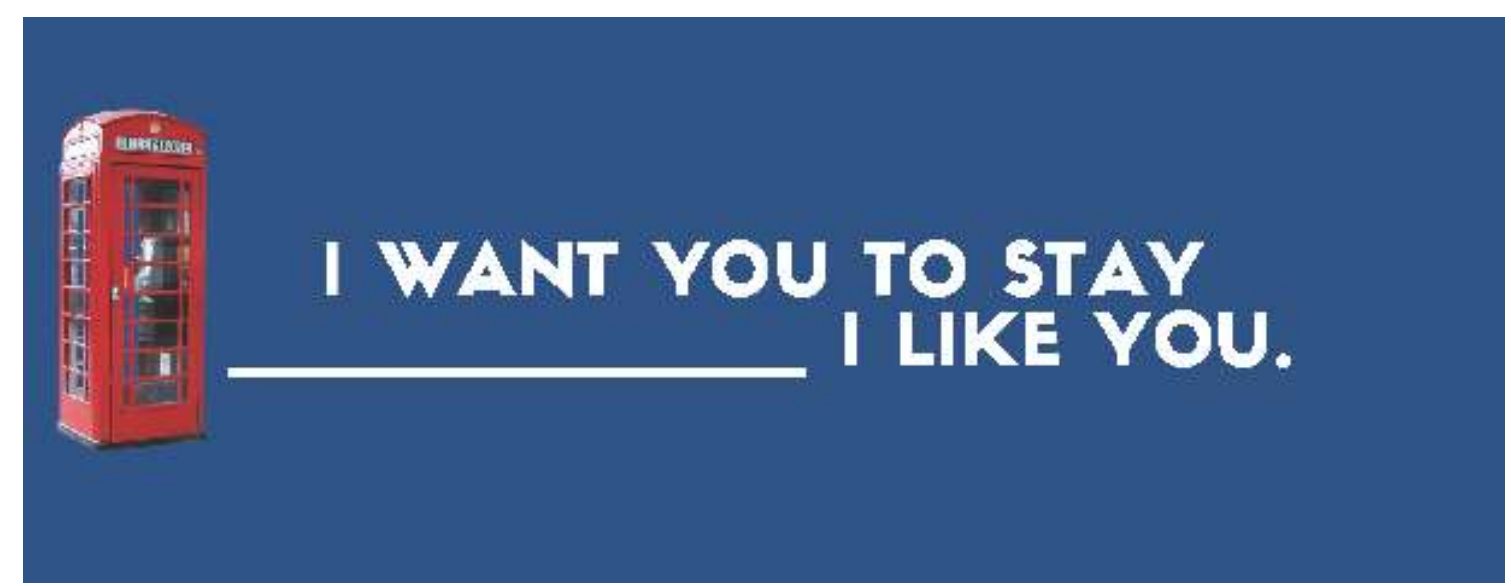

Imagem 3. Exemplo de um slide utilizado na dinâmica com a segunda metade do filme O jogo da imitação. Fonte: os autores.

Antes do início do jogo, o professor abriu uma breve discussão com a turma, para decidir se eles preferiam que duas equipes competissem até que uma ganhasse, ou se preferiam que essa atividade não fosse competitiva, apenas respondendo às questões apresentadas, mas sem marcar a pontuação. Enquanto apenas dois alunos queriam um jogo competitivo, a maioria esmagadora da turma optou por uma atividade não competitiva. Foi interessante que, apesar de termos pensado na atividade como um jogo competitivo, a sua adaptação não a invalidou como atividade pedagógica. Inclusive, acreditamos que o fato de termos aberto para a discussão e atendido ao anseio da turma foi um fator que contribuiu para o sucesso da dinâmica.

A atividade transcorreu sem problemas, com as equipes acertando praticamente todas as respostas. Em cada slide, os grupos tinham até 20 segundos para apresentar uma resposta, em forma de um cartão que se encontrava em uma classe. Os membros da equipe entravam em consenso e apresentavam as respostas. Os alunos não apresentaram dificuldades, exceto em alguns casos, em que o uso informal de algumas construções surpreendeu alguns alunos. 


\section{LínguaTec}

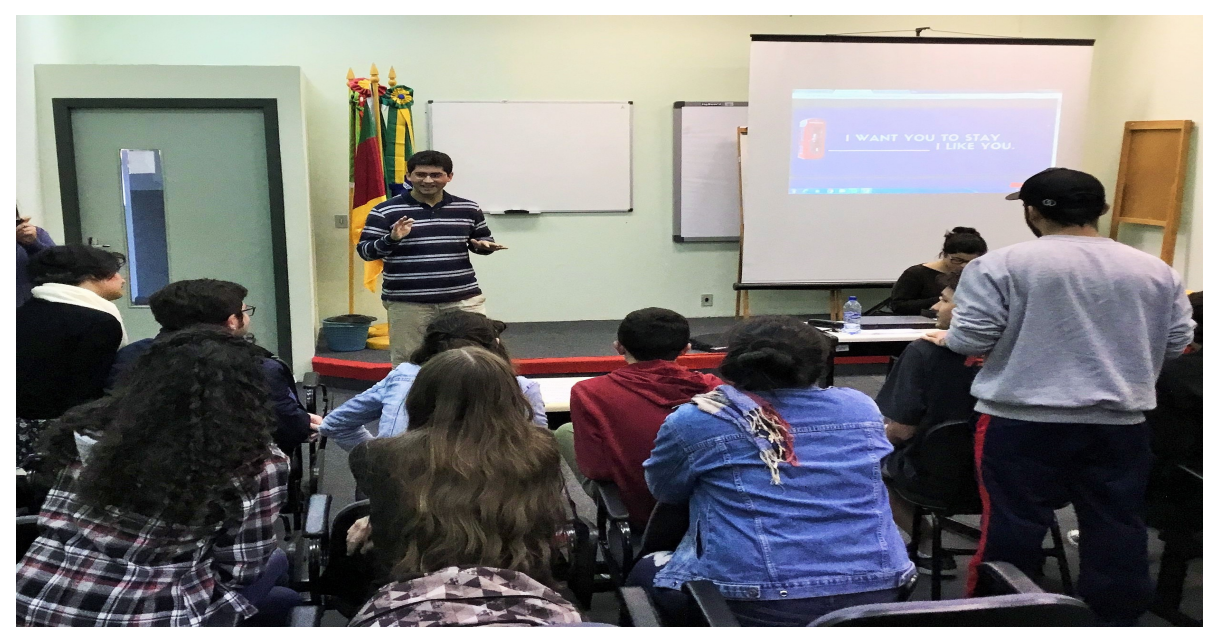

Foto 3. A turma realiza uma dinâmica com base na segunda metade do filme O jogo da imitação, no miniauditório do campus Osório do IFRS.

Fonte: os autores.

\section{Aprendendo com as avaliações}

Na semana seguinte, foram dedicados os últimos dois períodos ao assunto de adverbial clauses e ao filme 0 jogo da imitação, com dois instrumentos de avaliação linguística e um instrumento de avaliação da atividade por parte dos alunos. 0 primeiro instrumento de avaliação foi composto por 20 questões, em dois tipos de exercícios. No primeiro exercício, os alunos analisaram pares de questões com orações adverbiais $e$ verificaram se elas expressavam o mesmo sentido. No segundo exercício, de múltiplaescolha, os alunos escolhiam a palavra que se encaixava de forma correta para completar o sentido da frase e preservar a acurácia. Essa avaliação foi feita individualmente, com consulta ao dicionário e ao material sobre as orações adverbiais fornecido pelo professor, pois o foco da avaliação era a relação de sentidos entre as orações, e não sua classificação.

O segundo instrumento de avaliação enfatizou o uso comunicativo das orações adverbiais. Os alunos analisaram cinco perguntas em que estava faltando a conjunção ou a preposição que introduz a oração adverbial. Essa primeira parte apenas revisava o assunto $\mathrm{e}$ exigia que os alunos prestassem atenção ao sentido da questão. 0 objetivo maior era que os alunos conversassem sobre as questões, dando a sua opinião sobre temas abordados pelo filme. Um exemplo de questão que suscitou um debate interessante foi: “How do you think that prejudice against homosexuals has changed (answer: since) the time portrayed in the movie (1940's and 50's)?" Sabendo que esta é uma turma com nível heterogêneo de 
proficiência e que alguns alunos teriam dificuldades para sustentar uma conversa sobre assuntos polêmicos como esse, o professor orientou a turma a dedicar alguns minutos para fazer anotações com consulta a dicionários e, assim, preparar-se para a conversa. Notamos que a tarefa levou mais tempo do que inicialmente previsto e, em vez de 10 minutos de preparação, os alunos utilizaram aproximadamente o dobro de tempo, mas a conversa em pares aconteceu de forma bastante significativa, enquanto o professor circulava e auxiliava os alunos. Depois de aproximadamente 10 minutos de comunicação em duplas, o professor abriu a discussão para o grande grupo, e alguns alunos fizeram questão de se posicionar com relação às questões, já que todas possibilitavam que eles expressassem seus pontos de vista.

Com base nas avaliações, pudemos constatar que os alunos apresentaram um rendimento muito satisfatório com relação aos tópicos trabalhados, identificando as relações de sentido de orações subordinadas adverbiais e utilizando essas estruturas em uma comunicação sobre temas pertinentes em suas vidas, embora devamos reconhecer que a comunicação verbal ainda represente um grande desafio para alguns alunos.

Ao final, os alunos receberam um formulário em que eles foram convidados a dar feedback sobre as atividades realizadas com o filme. Pedimos que eles avaliassem apenas as atividades realizadas com o filme 0 jogo da imitação, para que a equipe de pesquisa pudesse refletir e melhorar as propostas pedagógicas.

O feedback dos alunos foi, de modo geral, bastante positivo. Todos os alunos que responderam ao questionário perceberam que o filme foi utilizado para o alcance de objetivos pedagógicos intimamente ligados ao plano de ensino. Eles enfatizaram como pontos positivos a importância da relação dos temas do filme com o seu curso técnico e a variedade das atividades, que não tornaram as aulas maçantes. A maioria avaliou as atividades como acessíveis e interessantes, embora uma aluna tenha apontado sua dificuldade pessoal na solução das questões da dinâmica em grupo (jogo). Alguns alunos destacaram de maneira positiva a aula em que o professor fez uma apresentação de slides sobre os tipos de orações adverbiais. É interessante observar que uma apresentação de slides sobre gramática geralmente é considerada uma atividade entediante para grande parte dos alunos, então a contextualização com o filme aqui fez toda a diferença na forma como os alunos vivenciaram essa aprendizagem. Também foi considerada pela turma uma 
decisão adequada a divisão do filme em duas partes, com atividades distribuídas antes da exibição da primeira parte, entre a primeira e a segunda parte e as posteriores à segunda exibição. Nesse sentido, essa organização foi apontada como uma melhoria com relação a atividades anteriores na mesma turma, quando trabalhamos com o filme Os estagiários (2013), pausando várias vezes o filme para a realização de tarefas.

\section{Considerações finais}

Consideramos que nosso maior objetivo foi alcançado com o desenvolvimento das atividades aqui narradas, já que conseguimos aliar temas e assuntos da área técnica dos alunos (informática) com tópicos de LI, utilizando o audiovisual como um recurso pedagógico que potencializa o processo de ensino-aprendizagem, pois desperta grande interesse dos alunos e fornece um rico contexto de uso da língua-alvo.

Com o desenrolar das atividades, aprendemos algo que nos surpreendeu de certa maneira e que pode servir de reflexão para a prática docente e o desenvolvimento de pesquisas sobre o uso do cinema no ensino de inglês. Quando iniciamos o projeto que serviu de base para essas atividades, pensamos que seria mais efetivo do ponto de vista pedagógico se o filme trabalhado apresentasse uma abundância de vocabulários e contextos de uso linguístico relacionados diretamente com a área técnica, mas ao trabalhar com o filme 0 jogo da imitação pudemos perceber que os alunos dessa turma se interessaram pelos aspectos relacionados à sua área, mas ficaram ainda mais instigados por temas e conflitos que dizem respeito às suas vidas como cidadãos e futuros profissionais, como relacionamentos interpessoais, sexualidade, ética, sigilo, guerra, etc. Por isso, lembrando a discussão de Araujo e Voss (2009, p. 125-126) sobre a importância dos temas transversais para o processo de projeção/identificação na relação espectador/espetáculo, constatamos que um critério fundamental no momento da seleção de filmes para o trabalho em cursos técnicos diz respeito aos temas transversais que podem ser abordados em conjunto com vocabulários, estruturas e funções da língua estrangeira em seu contexto de uso técnico.

Percebemos, também, que se fez necessário chamar a atenção da turma em alguns momentos para a seriedade das atividades, talvez por estarmos trabalhando com um meio 
geralmente associado ao entretenimento. Concluímos que, quando propomos aos alunos atividades com o cinema, é importante negociar com a turma o significado pedagógico desse trabalho. Isto é, deve ficar claro para a turma que, fazendo uso de um insumo divertido e envolvente como o audiovisual, as atividades exigem atenção e dedicação, caso contrário os alunos (e professores) parecem ter uma tendência a considerar as atividades apenas como diversão.

Conscientes das inúmeras possibilidades de atividades com filmes no ensino de inglês, em seus aspectos visuais, fotográficos, sonoros, temáticos, narrativos, etc., concluímos, com a vivência das lições aqui narradas, que talvez o único ponto fundamental em jogo seja que as atividades, partindo de necessidades e objetivos pedagógicos de uma turma específica, em um contexto educacional particular, envolvam os discentes de maneira que eles assumam um papel ativo com relação à sua aprendizagem com o uso de filmes, adotando, assim, a visão de que o cinema pode ser um grande aliado de professores e alunos de inglês ao promover experiências de ensino-aprendizagem mais eficazes e significativas.

\section{REFERÊNCIAS}

ARAUJO, A. R; VOSS, R. C. R. Cinema em sala de aula: identificação e projeção no ensino/aprendizagem da Língua Inglesa. Conexão, Comunicação e Cultura (UCS). v. 8, n. 15, 2009 .

BORDWELL, D; THOMPSON, K. Film Art: an introduction. New York: McGraw-Hill, 2008.

BROWN, H. D. Teaching by Principles. an interactive approach to language pedagogy. 3 ed. New York: Pearson Education, 2007.

CANAL, A. O cinema nas aulas de espanhol. LínguaTec. Bento Gonçalves, v. 2, n. 3, p. 10013, jun. 2017.

CINEMA E LÍNGUA INGLESA: O USO DO CINEMA NO ENSINO DA LÍNGUA INGLESA. Disponível em: <https://cinemaelinguainglesa.wixsite.com/cinemaelinguainglesa>. Acesso em: 20 set. 2018.

CINEMATIC CORNER. Disponível em: <https://cinematiccorner.blogspot.com/2015/o1/theimitation-game.html>. Acesso em: 29 set. 2018. 
KHAN, A. Using Films in the ESL Classroom to Improve Communication Skills of NonNative Learners. ELT Voices-International Journal for Teachers of English. v. 5, issue 4, 2015, p. 46-52.

O JOGO DA IMITAÇÃO. Dir. Morten Tyldum. Estados Unidos. StudioCanal, 2014.

OS ESTAGIÁRIOS. Dir. Shawn Levy. Estados Unidos: $20^{\text {th }}$ Century Fox, 2013. DVD.

PEREIRA, M. R.; ESPÍNDULA, D. S.; TEIXEIRA, C. M. S. P. G. O ensino da Língua Inglesa em tela: a mise-en-scène. LínguaTec. Bento Gonçalves, v. 3, n. 5, p. 22-50, jun. 2018.

Data de submissão: 30/09/2018. Data de aprovação: 13/11/2018. 